\section{Death and Dying: A reflection on how mourning changed during the pandemic}

\author{
Gabriel M. Alexandre Silva', Michelle Vanessa Santiago Franco', \\ Artur Diogenes Pinheiro Paiva', Isadora Sousa de Oliveira², \\ Manuela Berto Pucca ${ }^{*}$
}

${ }^{1}$ Medical School, Federal University of Roraima, Boa Vista, RR, Brazil 2Department of BioMolecular Sciences, School of Pharmaceutical Sciences of Ribeirão Preto, University of São Paulo, Ribeirão Preto, Brazil
Address for correspondence: Manuela Berto Pucca, Medical School of Roraima, Federal University of Roraima, Av. Capitão Ene Garcez, 2413, Boa Vista, RR, 69310-000, Brazil, E-mail: manupucca@ufrr.br

How to cite this article: Silva GMA, Franco MVS, Paiva ADP, Oliveira IS, Pucca MB. Death and Dying: A reflection on how mourning changed during the pandemic. G Med Sci. 2021; 2(1): 030-037.

https://www.doi.org/10.46766/thegms.pubheal.21020302

Copyright: (c) 2021 Gabriel M. Alexandre Silva, Michelle Vanessa Santiago Franco, Artur Diogenes Pinheiro Paiva, Isadora Sousa de Oliveira, Manuela Berto Pucca. This is an Open Access article distributed under the Creative Commons Attribution License, which permits unrestricted use, distribution, and reproduction in any medium, provided the original work is properly cited.

\begin{abstract}
Introduction: The pandemic scenario created by the Severe Acute Respiratory Syndrome - Coronavirus-2 (SARS-CoV-2) brought physical and psychological distress among people who found themselves under a situation which unabled most of them to proceed with their usual routine or rites of passing to cope with losses of lifestyle, relatives, and friends.
\end{abstract}

Objective: This short review explores the role of mourning rites as coping mechanisms in order to maintain mental stability during the stressing scenario proposed by the pandemic.

Methods: This review was performed by searching published articles in national and international journals indexed in the National Library of Medicine (PubMed), and Scientific Electronic Library Online (SciELO), using the keywords "SARS-CoV-2", "grief", "mourning", "pandemic", and "health models", both in Portuguese and English. We included papers published between 1996 and August 2020.

Discussion: Due to a cultural composition, the subject of both death and dying are mostly avoided. During the pandemic, the imposed sanitary measures disrupted most of the mourning process, which has a therapeutic role to both family and those surrounding them. Thus, the repercussions of this postdeath process during pandemic are causing mental and emotional conflicts for the family members, hindering the long-term coping process.

Conclusion: The pandemic scenario poses a challenge concerning the 'dignity' of dying, which has caused many mental problems in people involved. Thus, this aspect of pandemic requests much more attention of the health professionals. However, the narrow relationship of health professional with bereaved family members has generated anxiety, making the process of coping with post-death mourning even more difficult. Nonetheless, this challenge can be faced through holistic measures and appropriate support from both caregivers and civilians involved.

Keywords: SARS-CoV-2; Pandemics; Death; Mourning; Grief. 


\section{Resumo}

Introdução: O cenário de pandemia criado pelo Coronavírus-2 da Síndrome Respiratória Aguda Grave trouxe muitas mudanças nas vidas das pessoas, que se viram pegas em situação de estresse físico e psicológico, muitos sendo incapazes de seguir com suas rotinas e ritos para lidar com a perda tanto de seu estilo de vida quando de seus parentes e amigos.

Objetivos: Esta curta revisão explora o papel dos ritos de luto como mecanismos de enfrentamento que buscam manter a estabilidade mental diante do cenário estressor proposto pela pandemia e sua repercussão sobre a saúde mental de diversos indivíduos

Métodos: Esta revisão foi realizada através de uma pesquisa por artigos publicados em jornais indexados nacionais e internacionais na National Library of Medicine (PubMed) e Scientific Eletronic Library Online (SciELO) utilizando os descritores "SARS-CoV-2", "pesar" "luto", "pandemia" e "modelos de saúde", tanto em inglês quanto seus equivalentes em português. Foram inclusos artigos publicados entre 1996 e agosto de 2020 . Análise crítica após leitura detalhada dos artigos foi o fator determinante de inclusão.

Discussão: Em decorrência da composição cultural, os temas de morte e morrer são majoritariamente evitados, o que acaba por resultar em uma abordagem inadequada em relação ao cuidado do paciente e seus parentes. Durante a pandemia, as medidas sanitárias impostas interromperam a maioria dos processos de luto, o qual possui papel terapêutico para a família e aqueles que a cercam. Assim, as repercussões desse processo pósóbito implicam em conflitos tanto mentais quanto emocionais para os familiares envolvidos, dificultando o processo de enfrentamento a longo prazo.

Conclusão: 0 cenário de pandemia se mostra um desafio no que tange a dignidade de morrer, o que tem causando diversos problemas de ordem mental aos envolvidos. Portanto, o atual cenário demanda muito mais do que apenas atenção dos profissionais de saúde. A ínfima relação profissional de saúde com os familiares enlutados gera ansiedade generalizada, dificultando ainda mais o processo de enfrentamento do luto pós-óbito. Não obstante, é um desafio que pode ser enfrentado com medidas holísticas e suporte apropriado tanto de cuidadores quanto dos civis envolvidos.

Palavras-chave: SARS-CoV-2; Pandemias; Morte; Luto; Pesar.

\section{Introduction}

As the Severe Acute Respiratory Syndrome Coronavirus-2 (SARS-CoV-2) struck the world with a swift and widespread movement, many lifestyle changes were enforced onto the population as countermeasures in order to save as many lives as possible and to lower the resource consumption as much as possible [1]. The sudden changes into human lives represent a situation of distress, associated with the constant fear of the new disease, resulting in difficulties to people adapt to such stressful environment along with social distancing rules. Indeed, all these changes deeply affected psychology of people. The psychological situation even worsen during the mourning of a beloved person, since funerals are, in most countries, completely prohibited by law as a sanitary measure $[2,3]$.

This short review explores the role of mourning rites as coping mechanisms in order to maintain mental stability in face of the stressing scenario caused by the pandemic and its repercussion over the mental health of many individuals.

\section{Methods}

We searched 60 published articles in national and international journals indexed in the National Library of Medicine (PubMed), and Scientific Electronic Library Online (SciELO). We used the keywords "SARS-CoV-2", "grief", "mourning", "pandemic", and "health models" both in Portuguese and English. The analyzed period was between 1996 and August 2020, with a quarter of references from 2020.

\section{Discussion}

\section{SARS-CoV-2: the impact into human life}

Coronaviruses are part of a virus family known since 1960. Amongst the six different kinds of previously known coronaviruses, only two are capable of causing severe symptoms and have already caused a high impact on the public health worldwide: the Severe Acute Respiratory Syndrome - Coronavirus (SARS-CoV), affected China during the period of 2002 to 2003, and the Middle East Respiratory Syndrome - Coronavirus (MERS-CoV), afflicted the middle east specially in 2012. Despite most of coronavirus family members cases only cause mild respiratory symptoms, it is undeniable the worry warranted by the ascension of the new coronavirus, named SARS-CoV-2 $[1,4]$.

Although SARS-CoV-2 lethality is significantly lower when compared to both SARS-CoV and MERS-CoV, the pandemic scenario resulted in a higher absolute number of cases. According to the World Health Organization (WHO, https://covid19.who.int/) it was registered more than 105 million confirmed cases worldwide so far (data collected on 02.11.2021). In fact, the widespread infection evolved to such a point that changed the way of living throughout the world, despite the high investment in resources seeking to contain the viral spread. Moreover, the SARS-CoV-2 created the need of holistic actions to mitigate the damage and the population mental health, since most people do not possess emotional support to deal with a stressful environment $[1,3][5-7]$.

In this context, it is necessary to find a way to assist those with greater vulnerability, prone to develop disorders in their mental health during and after the pandemic scenario, aiming to support the death rituals of people close to them. 
It is known that each individual sustains a deep and intricate series of needs, ranging from material to psychological needs, which can be as simple as food and water, or can be something more complex, such as an adequate social interaction [8]. Nevertheless, the pandemic scenario created a hindering environment, capable of either limit or completely prevent the adequate acquisition of all these necessary elements. It is necessary to remember that the basic human needs are classically categorized as biophysical and psychological, and the pandemic per se created a stressful factor under the biophysical aspect (the need to avoid dangers in the environment), along with many psychological damages caused mainly by the social distancing [9].

On worse conditions, there are people who were put into a socially frail position and turned to be unable to provide for themselves. These people are represented mainly by informal workers and people with low income, which do not have savings or financial stability to pass through the imposed economic situation, creating the demand for governmental measures. Thus, especially for this lowincome population, a network of solidarity (including health workers and any kind of people) is extremely necessary. In fact, both individual and governmental measures are able to prevent many mental complications brought by economic crisis and social withdrawal on coping strategies [3][10-13].

\section{The way modern western society deals with death and dying}

Due to a societal composition centered around longevity, youth, and health, the discussion of themes that brings up the human finitude are usually faced with certain strangeness or even avoided under the false guise that 'negation' would be enough to spare the suffering that permeates the event $[14,15]$.

The discussion regarding the death and the process of dying is equally important as this dichotomy is frequently a motive for reflection. There are different interpretations for both terms: (i) Death can be considered a gradual phenomenon, in which an individual dies slightly every day (i.e. being a synonym of dying), therefore dying would be a process through the natural cycle of existence, in other words, to live is to die until the person reaches the death. (ii) Another interpretation presents death as the final event where an individual has its life finished $[16,17]$.

We cannot deny the fact that death, both as event and process, is a result of both social and historical context, along with personal interpretations and coping techniques, which are built upon personal values and experiences including health condition and spirituality $[18,19]$. It is interesting to understand how different cultures handle the process of death and mourning considering the religious symbolism [20-22]. For instance, the traditional African belief assumes that the course of life is cyclical, therefore supporting the thought that the deceased has merely faced a passage to another world [23]. While the ancient Persian tradition, following the Zoroastrianism, deals death with calm and acceptance, in a process surrounded by family and friends and even witnessed by children. Since they considered the soil as a pure element, they did not bury their bodies, instead allocating them in special places (Dakhmeh) to be decomposed or eaten by animals [24]. Additionally, Abrahamic religions such as Judaism and Catholicism hold the tradition of performing the last rites of a person in their deathbed, as a mean to provide both the family and the person spiritual solace. These religions present different means and peculiarities during mourning rituals, such as ointments or confessions to Catholics, or familial prayers of affirmation and hope of "salvation" in the afterlife in Judaism. Even though, death still stays a taboo topic [25].

It is noticeable the human need of providing and attributing meaning to the elements that permeate the finitude as a way to seek solace in a more familiar environment, making it capable of providing greater comfort and lessen the suffering [26]. In fact, it is a traditional part of human nature to seek meaning in phenomena that surround the existence. Such anthropocentric vision is extremely present in human lives, which are centered around meaningful events created by ourselves in order to point the flow of life [27].

\section{The grief and the role to overcoming events}

One of the pivotal factors of discussion are the phases that compose the grief, traditionally described by Kubbler-Ross (Fig. 1). The grief stages are markers of individual reaction after the death situation. They might be predisposed to last more or less in each specific stage according to particularities of the environment surrounding the person, such as cultural behavior, religious rites, and familial customs [28-30]. Many authors argue and criticize such an over-simplified model, while working in favor of a more fluid and complex model upon the overlapping of more stages. Others completely disagree with any grief model, believing that the grief and bereavement are singular to each individual and yet unsuccessfully described [31-33]. 


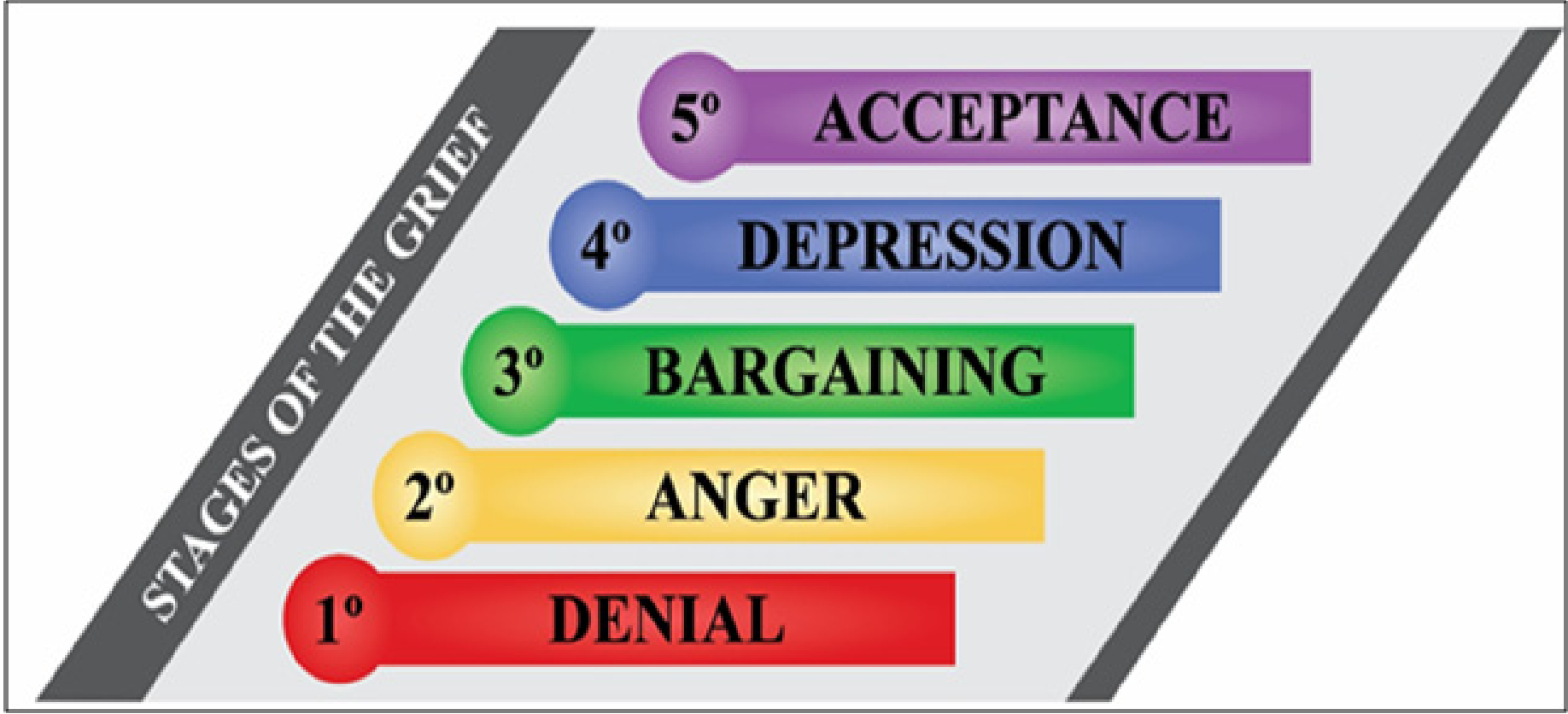

Figure 1. Five stages of the grief. Sequence of phases presented by an individual during mourning: denial, anger, bargaining, depression, and acceptance [34].

Regarding the discussion over the mourning composition and its manifestation as a phenomenon, it is undeniable the necessity that people have of coping mechanisms and instruments to deal and overcome stressful events in a healthy manner, seeking to decrease the possibility of emotional disorders. Thus, the grief broadens its definition to a sensation of loss, not being exclusively tied to death, therefore being applicable to relationships and lifestyles [35-37].

The funeral rites, which predate written history, are a necessary part of a healthy mourning and act as the representation of needs and beliefs, allowing people to express their feeling and consolidate bonds with those nearby as an assistance network in order to push through tough times $[38,39]$. These passing rites hold a role as a therapeutic measure, as it helps the family to affirm the value of the deceased as much as their own, placing their lives in different perspectives and even serving as protective factor against emotional scarring $[40,41]$.

Thus, during the pandemic due to COVID-19, feelings of insecurity and uncertainty were automatically increased and all of those involved with the grief (e.g. patient, healthcare workers, and the social circle of the diseased) were suffering a much higher emotional impact, requiring proper coping mechanisms. Thankfully, psychological coping mechanisms can be applied by a healthcare team to support patients, family circle, and colleagues, aiming to mitigate the mental health of these individuals [42-46].
A coping mechanism can be defined as "something that promotes resilience against traumatic experiences". The examples of coping mechanisms are: (1) Innate personality traits or appliable mindsets, audacity being an example of both, taking into consideration the meaning of "being able to face and learn from both positive and negative experiences"; (2) The availability of a religious creed, as it should provide a refuge; (3) The sense of belonging to a group or community, as the individual won't feel isolated under the stressful event; (4) Psychotherapy focused on restructuring and providing new meaning to previous events. Moreover, mechanisms derived from individual experiences shouldn't be neglected, such as pleasurable activities that work as a reliever of the stressful moment, or the mourning rite itself, as they provide a sense of comfort under a controlled situation. [20,27,33,36,40]

\section{Shifts in the healthcare model and its impacts over the mourning process}

The healthcare system is still centered around hospital units, according to the biomedical standard. The mentioned centralization leads to several problems that negatively impact the quality of the health assistance, especially regarding psychological assistance [47-50]. With the pandemic scenario, these problems got even worse, with an unrealistic expectation of an immediate and invasive solution. The expectation of immediate cure delays or at least acts as a barrier to a proper way to address the death during the pandemic period [47-49]. The referred problem can be even more prevalent in patients that, due to chronic or acute disease (e.g., long term cancer, vascular event, etc.) are nearing the end of 
life [51-55]. Thus, proper approach regarding palliative care (to be under the program of palliative care does not mean that the health team has given up on the patient and will not care for it) is necessary as a protective measure to the psychological health of both the patient and their families.

The adequate execution and offer of palliative care in any situation (during pandemic or not) reflect directly the quality of the health service to the population as well as the costs for the health system. Palliative care intends not to delay artificially a situation that cannot be reverted, but to guarantee the right to die without suffering and with dignity as the health team will always fight to save a life, no matter how small seems to be the chance [47][51-54]. Other related problem lies in communication. It has been proven that proper communication between the patient/ family and the assistant professional not only increases the assistance quality, but also lowers the rates of judicial dispute, as the family takes part of the whole treatment and understands the processes performed by the hospital or health unit. Although communication is a fundamental element present on routine of health professionals, it can be affected by the overwhelmed team during pandemic [56-58].

Recent changes imposed by the evolution of the health sciences have laid ground to the creation of a new model of care, centered in the patient, aiming to cover all of the complexity that a person represents, avoiding to center the assistance to the illness or disease [59]. Thus, the patient-centered healthcare model can provide proper assistance and approach to both patient and family, acting through multidisciplinary teams that provide the best assistance and care [60].

Therefore, it is highly recommended that a patientcentered care model associated with multidisciplinary teams are implemented in order to optimize the resources available and allow the patient and its family to receive the much needed assistance in their time of distress.

\section{Conclusion}

It is a noticeable challenge to deal with a scenario of widespread anxiety and social reclusion, where the process of mourning is interrupted due to quarantine and isolation during 2020 pandemic. The isolation recommended for individual protection also reduced psychosocial support offered by overwhelmed health teams to bereaved family members, either due to the risk of contamination or the requirement for rapid intensive care, thus generating a scenario of psychological damage and confinement. Nonetheless, all these consequences imposed by COVID-19 could be overcome with holistic measures and appropriate support from both caregivers and civilians involved.

\section{Conflicts of Interest}

The authors declare no conflict of interest.

\section{Funding}

We thank Fundação de Amparo à Pesquisa do Estado de São Paulo (FAPESP, São Paulo Research Foundation; scholarships to ISO no. 2017/03580-9 and Conselho Nacional de Desenvolvimento Científico e Tecnológico (CNPq, The National Council for Scientific and Technological Development, scholarship to MBP no. 307155/2017-0).

\section{References}

1. Pimentel R, Daboin B, Oliveira A, Jr H. The dissemination of COVID-19: an expectant and preventive role in global health. J Hum Growth Dev. 27 de março de 2020; 30:135-40.

2. McIvor DW, Hooker J, Atkins A, Athanasiou A, Shulman G. Mourning work: Death and democracy during a pandemic. Contemp Polit Theory [Internet]. 20 de julho de 2020; Disponível em: https://doi.org/10.1057/s41296-020-00421-5

3. Torales J, O’Higgins M, Castaldelli-Maia JM, Ventriglio A. The outbreak of COVID-19 coronavirus and its impact on global mental health. Int J Soc Psychiatry. 31 de março de 2020; 66(4):317-20.

4. Malik YA. Properties of Coronavirus and SARS-CoV-2. Malays J Pathol. abril de 2020; 42(1):311.

5. Han $\mathrm{Y}$, Yang $\mathrm{H}$. The transmission and diagnosis of 2019 novel coronavirus infection disease (COVID-19): A Chinese perspective. J Med Virol. 2020/03/12 ed junho de 2020; 92(6):639-44.

6. Rasmussen SA, Smulian JC, Lednicky JA, Wen TS, Jamieson DJ. Coronavirus Disease 2019 (COVID-19) and pregnancy: what obstetricians need to know. Am J Obstet Gynecol. maio de 2020;222(5):415-26.

7. Chen Y, Liu Q, Guo D. Emerging coronaviruses: Genome structure, replication, and pathogenesis. J Med Virol. $1^{\circ}$ de abril de 2020; 92(4):418-23. 
8. Bergman R. Understanding the patient in all his human needs. J Adv Nurs. maio de 1983; 8(3):185-90.

9. Henderson Virginia, International Council of Nurses. Basic principles of nursing care. London: [International Council of Nurses]; 1961.

10. Mowbray H. In Beijing, coronavirus 2019-nCoV has created a siege mentality. BMJ [Internet]. 2020;368. Disponível em: https://www.bmj.com/ content/368/bmj.m516

11. Van Assche J, Politi E, Van Dessel P, Phalet K. To punish or to assist? Divergent reactions to ingroup and outgroup members disobeying social distancing. Br J Soc Psychol. julho de 2020; 59(3):594606.

12. Castro-de-Araujo LFS, Machado DB. Impact of COVID-19 on mental health in a Low and Middle-Income Country. Ciênc Saúde Coletiva. 2020;25:2457-60.

13. Lai J, Ma S, Wang Y, Cai Z, Hu J, Wei N, et al. Factors Associated with Mental Health Outcomes Among Health Care Workers Exposed to Coronavirus Disease 2019. JAMA Netw Open. 2 de março de 2020; 3(3):e203976.

14. Afonso SBC. Sobre a morte e o morrer. Ciênc Saúde Coletiva. 2013; 18:2781-2.

15. Araújo PVR de, Vieira MJ. A questão da morte e do morrer. Rev Bras Enferm. 2004; 57:361-3.

16. Kovács MJ. Desenvolvimento da Tanatologia: estudos sobre a morte e o morrer. Paid Ribeirão Preto. $2008 ; 18: 457-68$.

17. Praxedes AM, Araújo JL de, Nascimento EGC do. A morte e o morrer no processo de formação do enfermeiro. Psicol Saúde Doenças. 2018; 19:36976.

18. Oliveira A, Amâncio L. Influência do contexto na percepção e nas representações sociais da morte. Psicologia. 1998; 12:213-35.

19. Ohnsorge K, Gudat H, Rehmann-Sutter C. What a wish to die can mean: Reasons, meanings and functions of wishes to die, reported from 30 qualitative case studies of terminally ill cancer patients in palliative care. BMC Palliat Care. 2014; 13:38.

20. Santos MA dos, Hormanez M. Atitude frente à morte em profissionais e estudantes de enfermagem: revisão da produção científica da última década. Ciênc Saúde Coletiva. 2013; 18:2757-68.

21. Souza CP de, Souza AM de. Rituais Fúnebres no Processo do Luto: Significados e Funções. Psicol Teor E Pesqui [Internet]. 2019; 35. Disponível em: http://www.scielo.br/scielo.php?script=sci arttext\&pid=S0102-37722019000100509\&nrm=iso

22. Chamas FC. Origens das formas budistas. ARS São Paulo. 2015;13:104-13.

23. Ekore RI, Lanre-Abass B. African Cultural Concept of Death and the Idea of Advance Care Directives. Indian J Palliat Care. dezembro de 2016;22(4):369-72.

24. Aramesh K. History of attitudes toward death: a comparative study between Persian and western cultures. J Med Ethics Hist Med. 2016; 9:20.

25. Gordon M. Rituals in death and dying: modern medical technologies enter the fray. Rambam Maimonides Med J. 29 de janeiro de 2015; 6(1): e0007-e0007.

26. Rezende ALM de, Santos GF dos, Caldeira V da P, Magalhães ZR. Ritos de morte na lembrança de velhos. Rev Bras Enferm. 1995; 48:07-16.

27. Neimeyer RA. Reconstructing meaning in bereavement: summary of a research program. Estud Psicol Camp. 2011; 28:421-6.

28. Kübler-Ross E, Menezes P, Kellehear A. Sobre a morte e o morrer: O que os doentes terminais têm para ensinar a médicos, enfermeiras, relogiosos e aos seus próprios parentes [Internet]. WMF Martins Fontes; 2017. Disponível em: https://books. google.com.br/books?id=MDTGDgAAQBAJ

29. Susaki TT, Silva MJP da, Possari JF. Identificação das fases do processo de morrer pelos profissionais de Enfermagem. Acta Paul Enferm. 2006; 19:144-9.

30. Afonso SBC, Minayo MC de S. Uma releitura da obra de Elisabeth Kubler-Ross. Ciênc Saúde Coletiva. 2013;18:2729-32. 
31. Stroebe M, Schut H, Boerner K. Cautioning Health-Care Professionals. Omega. março de 2017; 74(4):455-73.

32. Shuchter SR, Zisook S, Stroebe M, Stroebe W, Hansson R. Handbook of Bereavement: Theory, Research, and Intervention. Cambridge University Press Cambridge; 1993.

33. Neimeyer RA. Searching for the meaning of meaning: grief therapy and the process of reconstruction. Death Stud. setembro de 2000;24(6):541-58.

34. Kübler-Ross E. On death and dying. 1969.

35. Hamilton IJ. Understanding grief and bereavement. Br J Gen Pract J R Coll Gen Pract. outubro de 2016; 66(651):523.

36. Stroebe M, Schut H. The dual process model of coping with bereavement: rationale and description. Death Stud. maio de 1999; 23(3):197-224.

37. Freud S, Breuer J. The standard edition of the complete psychological works of Sigmund Freud. Vol. 2. Random House; 2001.

38. Gonçalves Júnior J, Moreira MM, Rolim Neto ML. Silent Cries, Intensify the Pain of the Life That Is Ending: The COVID-19 Is Robbing Families of the Chance to Say a Final Goodbye. Front Psychiatry. 2020; 11:978.

39. Gonçalves AC. Rituais tradicionais de solidariedade: religião e tensões entre finitude e infinitude. 2001.

40. Peres JF, Mercante JP, Nasello AG. Promovendo resiliência em vítimas de trauma psicológico. Rev Psiquiatr Rio Gd Sul. 2005; 27(2):131-8.

41. Bromberg MHPF. A psicoterapia em situações de perdas e luto [Internet]. Editora Livro Pleno; 2000. Disponível em: https://books.google.com. br/books?id=EbMxAAAACAAJ

42. Oates JR, Maani-Fogelman PA. Nursing Grief and Loss. In: StatPearls. Treasure Island (FL): StatPearls Publishing; 2020.

43. Grief, Bereavement, and Coping With Loss ( PDQ )Health Professional Version. In 2018.
44. Brown C, Ruck Keene A, Hooper CR, O’Brien A. Isolation of patients in psychiatric hospitals in the context of the COVID-19 pandemic: An ethical, legal, and practical challenge. Int J Law Psychiatry. agosto de 2020; 71:101572.

45. Liu Q, Luo D, Haase JE, Guo Q, Wang XQ, Liu $\mathrm{S}$, et al. The experiences of health-care providers during the COVID-19 crisis in China: A qualitative study. Lancet Glob Health. junho de 2020;8(6):e790-8.

46. Garner JS. Guideline for isolation precautions in hospitals. The Hospital Infection Control Practices Advisory Committee. Infect Control Hosp Epidemiol. janeiro de 1996; 17(1):53-80.

47. Rome RB, Luminais $\mathrm{HH}$, Bourgeois DA, Blais $\mathrm{CM}$. The role of palliative care at the end of life. Ochsner J. Winter de 2011; 11(4):348-52.

48. Constantino MJ, Arnkoff DB, Glass CR, Ametrano RM, Smith JZ. Expectations. J Clin Psychol. fevereiro de 2011; 67(2):184-92.

49. Bowling A, Rowe G, Lambert N, Waddington M, Mahtani KR, Kenten C, et al. The measurement of patients' expectations for health care: a review and psychometric testing of a measure of patients' expectations. Health Technol Assess Winch Engl. julho de 2012;16(30): i-xii, 1-509.

50. RAM D, GOWDAPPA B. Trust and expectation on psychiatrist and its correlation with satisfaction and adherence in patients with mental illness. Arch Clin Psychiatry São Paulo. 2015; 42:13-7.

51. Bremner KE, Krahn MD, Warren JL, Hoch JS, Barrett MJ, Liu N, et al. An international comparison of costs of end-of-life care for advanced lung cancer patients using health administrative data. Palliat Med. dezembro de 2015; 29(10):918-28.

52. Scitovsky AA. "The high cost of dying": what do the data show? 1984. Milbank Q. 2005; 83(4):82541.

53. Zuckerman RB, Stearns SC, Sheingold SH. Hospice Use, Hospitalization, and Medicare Spending at the End of Life. J Gerontol B Psychol Sci Soc Sci. maio de 2016; 71(3):569-80. 
54. Menezes MB de, Selli L, Alves J de S. Dysthanasia: nursing professionals' perception. Rev Lat Am Enfermagem. 2009; 17:443-8.

55. Menezes RA. Health professionals and death: emotions and management ways. Teor Soc. 2006; 2:0-0.

56. Campos RA de C, Camargo RAE, Neves LR. The judicialization of the medical act. Braz J Otorhinolaryngol. 2016; 82:1-2.

57. Chipidza FE, Wallwork RS, Stern TA. Impact of the Doctor-Patient Relationship. Prim Care Companion CNS Disord. 2015; 17(5).
58. Epstein RM, Street RLJ. The values and value of patient-centered care. Ann Fam Med. abril de 2011; 9(2):100-3.

59. Greene SM, Tuzzio L, Cherkin D. A framework for making patient-centered care front and center. Perm J. Summer de 2012; 16(3):49-53.

60. Ndoro S. Effective multidisciplinary working: the key to high-quality care. Br J Nurs Mark Allen Publ. 10 de julho de 2014; 23(13):724-7 